Volume. 7 Nomor. 2, Mei 2020. p - 2354-8649 I e - 2579-5767

Open Access at: http://ojs.umrah.ac.id/index.php/selat

DOI: https: https://doi.org/10.31629/selat.v7i2.2232

\title{
SUATU ANALISIS TERHADAP PERLINDUNGAN HUKUM INDIKASI GEOGRAFIS DI PROPINSI RIAU
}

\author{
Nur Aisyah Thalib ${ }^{1}$, Budi Santoso ${ }^{2}$, Sartika Nanda Lestari ${ }^{3}$ \\ ${ }^{123}$ Fakultas Hukum, Universitas Diponegoro, Semarang, Indonesia \\ email: nuraisyahthalib@yahoo.com
}

\begin{abstract}
That actually Intellectual Property is a material right that has commercial value with great potential. Today's global trade is dominated by various forms of products from the intellectual property of various countries. In principle, countries that have many of these products, and strong Intellectual Property provisions will dominate business competition. The study here intends to analyze policies and barriers to protection of Intellectual Property Rights (IPR) especially in the field of Geographical Indications in Riau Province. This paper is more dominant using the type of normative juridical research. To complete this paper, empirical research forms are also used, by gathering data from survey results in the field. Based on the research results, it is known that the Riau Provincial Government's policy in providing legal protection against IG's did not proceed as expected. Proven that there are no Regional Regulations in the Province or regencies and cities that regulate IG. The inhibiting factors in protecting IG's in Riau Province are the absence of Regional Regulations governing IG's, the low legal awareness of the people of Riau Province against IG's, the absence of an entrepreneurial spirit among Riau Provincial Government officials, and insufficient expertise in controlling products Quality IG.
\end{abstract}

Keywords; Policy, Geographical Indications, Riau.

\begin{abstract}
Abstrak
Bahwa sesungguhnya Kekayaan Intelektual itu adalah suatu hak kebendaan yang memiliki nilai komersial dengan potensi yang besar. Perdagangan global dewasa ini sangat didominasi oleh beragam bentuk produk dari hasil Kekayaan Intelektual berbagai negara. Prinsipnya, Negara-negara yang memiliki banyak produk-produk tersebut, dan ketentuan Kekayaan Intelektual yang kuatlah akan mendominasi atau menguasai persaingan bisnis. Kajian di sini bermaksud untuk menganalisis tentang kebijakan dan hambatan perlindungan Hak Kekayaan Intelektual (HKI) khususnya dalam bidang Indikasi Geografis di Propinsi Riau. Tulisan ini lebih dominan menggunakan jenis penelitian yuridis normatif. Untuk melengkapi tulisan ini, turut digunakan bentuk penelitian empiris, dengan mengumpulkan data dari hasil survei di lapangan. Berdasarkan hasil penelitian diketahui kebijakan Pemerintah Propinsi Riau dalam memberikan perlindungan hukum terhadap IG tidak berjalan sebagaimana yang diharapkan. Terbukti belum adanya Peraturan Daerah di Propinsi maupun kabupaten dan kota yang mengatur tentang IG. Adapun faktor penghambat dalam melindungi IG yang ada di Propinsi Riau adalah belum adanya Peraturan Daerah yang mengatur tentang IG, kesadaran hukum masyarakat Propinsi Riau yang rendah terhadap IG, tidak adanya jiwa kewirausahaan di kalangan aparat Pemerintah
\end{abstract}


Propinsi Riau, serta belum cukupnya tenaga ahli dalam mengontrol produk IG yang berkualitas.

Kata Kunci; Kebijakan, Indikasi Geografis, Riau.

\section{PENDAHULUAN}

Perlindungan Hak Kekayaan Intelektual (selanjutnya disingkat HKI) tidak dapat dilepaskan dari persoalan kegiatan pembangunan ekonomi, karenanya HKI identik dengan komersialisasi karya intelektual. Pada gilirannya perlindungan HKI menjadi tidak relevan apabila tidak dikaitkan dengan proses atau kegiatan komersialisasi HKI itu sendiri. Sebagaimana Trade Related Aspects of Intellectual Property Rights (selanjutnya disingkat TRIPs) Agreement mengatur kesepakatan perdagangan internasional bidang HKI telah berupaya mengakomodir secara umum berkenaan dengan perlindungan HKI. Beberapa pihak bahkan mengatakan bahwa TRIPS merupakan sebuah terobosan dalam kerjasama di bidang perdagangan internasional.

Seiring dengan itu Pemerintah Indonesia beberapa waktu yang lalu, telah melakukan terobosan baru terhadap ketentuan HKInya yaitu, mengundangkan dan memberlakukan Undang-undang Nomor 20 Tahun 2016 Tentang Merek dan Indikasi geografis. Ketentuan ini telah menggantikan Undang-undang No.15 Tahun 2001 Tentang Merek yang lama dan memasukkan tentang Indikasi Geografis (selanjutnya disingkat IG) ke dalam ketentuan yang baru. Inilah bukti keseriusan Pemerintah terhadap perlindungan IG di Indonesia.

Prinsipnya, Indonesia telah melakukan ratifikasi terhadap TRIPs dalam Undang-undang Nomor 7 Tahun 1994 mengenai persetujuan pembentukan Organisasi Perdagangan Dunia (selanjutnya disingkat WTO) pada 2 Nopember $1994 .{ }^{1}$ IG (geograpical indication) pertama kali tertuang dalam norma persetujuan TRIP's yang merupakan pengembangan dari aturan mengenai appellation of arigin (selanjutnya disingkat $\mathrm{AO}$ ) sebagaimana diatur dalam the Paris Convention for the Protection of Industrial Property 1883 (selanjutnya disingkat Konvensi Paris 1883) sebagai berikut:. ${ }^{2}$

1Undang-undang Nomor 7 Tahun 1994 Tentang Pengesahan Agreement Establishing the world Trade Organization (TRIPs).

2 Konvensi Paris Tahun 1883 Tentang Perlindungan Kekayaan Industri. 
"The geographical name of a country, region, or locally which serves to designate a product originating therein, the quality and characteristic of which are due exclusive or essentially to the geographical environment, including natural and human factor."

Dilihat dari aspek ekonomi, IG mempunyai daya komersil dan nilai unik karena suatu barang atau produk yang dihasilkan dari suatu daerah memiliki karakteristik yang berbeda dengan daerah lainnya. Hal ini disebabkan oleh faktor geografis seperti curah hujan, ketinggian daerah, suhu udara. IG termasuk pada kategori perlindungan terhadap kekayaan intelektual. Dimana HKI adalah hak atas kekayaan yang timbul karena kemampuan manusia. Ini merupakan perlindungan hukum bagi orang yang dapat mengembangkan, menemukan dan menciptakan suatu kekayaan intelektual. ${ }^{3}$ Selanjutnya pada tahun 2006, Indonesia meratifikasi Madrid agreement dan Singapore Treaty. Tujuannya agar menjadikan hukum sebagai alat pembangunan ekonomi serta menjadi daya tarik bagi investor untuk menanamkan modalnya di Indonesia. Hal ini didukung oleh Badan Ekonomi Kreatif Nasional sehingga mampu meningkatkan jumlah inovasi kreativitas masyarakat Indonesia.

Komitmen Indonesia dalam mengintegrasikan perlindungan IG merupakan dibuktikan dengan diaturnya dalam Peraturan Pemerintah Nomor 51 Tahun 2007 Tentang Indikasi Geografis merupakan penjabaran dari Undang-undang Nomor 20 Tahun 2016 Tentang Merek dan Indikasi Geografis adalah menggantikan UU No. 15 Tahun 2001 Tentang Merek. Nama hasil dari IG biasanya menambahkan nama daerah dan menjadi pembeda antara produk atau benda yang sejenis dan dihasilkan oleh daerah lain.

IG dapat dimohonkan terhadap barang-barang berupa hasil pertanian, produk olahan, hasil kerajinan tangan, atau barang lainnya. Banyaknya produk daerah yang ada di Indonesia yang telah dikenal dan mendapatkan tempat di pasar internasional sehingga memiliki nilai ekonomi yang tinggi, sehingga perlu diikuti dengan perlindungan hukum untuk bisa melindungi komoditas tersebut dari praktek persaingan curang dalam perdagangan. Sebagai contoh IG yaitu: Kopi Gayo, Kopi Kintamani, Kopi Toraja, Salak Pondoh Yogya, Ubi Cilembu, Meubel Jepara, Kopi Rangsang Meranti, dan sebagainya.

3Sudaryat, Sudjana, dan Rika Ratna Permata, (2010), Hak Kekayaan Intelektual, Memahami Prinsip Dasar, Cakupan Dan Undang-Undang Yang Berlaku, Oase Media, Bandung, hlm. 5. 
Data yang diperoleh dari Direktorat Jendral Hak Kekayaan Intelektual Kementrian Hukum dan Hak Asasi Manusia, bahwa hingga tahun 2018, IG yang terdaftar sejumlah 67 (enam puluh tujuh) buah. ${ }^{4}$ Angka ini masih sangat jauh dari harapan, mengingat tiap-tiap daerah di Indonesia tidak terkecuali setiap kabupaten di Propinsi Riau memiliki produk khas unggulannya masing-masing. Dikatakan produk khas dikarenakan barang-barang yang dimaksud mempunyai karakteristik khusus yang hanya ada di daerah yang bersangkutan, dan tidak dapat diperoleh di daerah lain yang berkualitas, reputasi, dan ciri-ciri lainnya dari barang tersebut secara esensial berkaitan dengan asal geografisnya. ${ }^{5}$

Propinsi Riau memiliki banyak potensi IG, tetapi anehnya baru hanya satu IG yang telah didaftarkan di Kementerian Hukum dan Hak Asasi Manusia, yaitu Kopi Liberika Rangsang Meranti yang berasal dari Kabupaten Kepulauan Meranti. ${ }^{6}$ Selain itu masih ada beberapa komoditas dari Propinsi Riau yang menjadi potensi IG lainnya, yaitu: lempuk durian dari Bengkalis, sagu dari Meranti, nenas dari Kampar dan Siak, serta pohon nibung dari Daerah Pesisir yang merata di Riau.

Selain dari yang dijelaskan di atas, masih ada banyak lagi potensi IG yang tidak mendapatkan perhatian yang baik dan serius dari pemerintah setempat khususnya instansi terkait di kabupaten - kabupaten di Propinsi Riau. Pemerintah tidak mendukung potensi atas IG tersebut yang memiliki nilai ekonomis bagi Propinsi Riau. Berdasarkan latar belakang tersebut penulis tertarik untuk melakukan penelitian tentang masalah "Perlindungan Hukum Terhadap Indikasi Geografis Di Propinsi Riau".

\subsection{Rumusan Masalah}

Berdasarkan uraian-uraian yang telah dikemukakan di atas, maka dapat dirumuskan permasalahan agaimana kebijakan Pemerintah Propinsi Riau dalam melindungi potensi-potensi IG yang ada di Propinsi Riau berdasarkan Undang-

\footnotetext{
4 Wawancara dengan Kasi Pemeriksaan Substansi Indikasi Geografis Bapak Saky Septiono, S. H., M. H., di Kantor Menkumham (Jakarta), tanggal 24 Desember 2019.

5 Tavinayati, (2016), M. Effendy, Zakiyah dan M. Taufik Hidayat, Perlindungan terhadap hak kekayaan inteletktual, indikasi geografis hasil pertanian lahan basah sebagai produk khas Propinsi Kalimantan Selatan, Badamai Lau Journal bol.1, Issue 1, fakultas Hukum Universitas Lampung, Lampung, April, hlm. 80.

6 http: //www.dgjp.go.id., diakses pada tanggal 26 Desember 2019.
} 
undang Nomor 20 Tahun 2016 dan apa faktor Penghambat dalam meningkatkan IG yang ada di Propinsi Riau berdasarkan Undang-undang Nomor 20 Tahun 2016?

\section{METODE PENELITIAN}

Kajian terhadap tulisan ini lebih dominan menggunakan jenis penelitian kepada bentuk yuridis normatif. Untuk melengkapi kajian di sini, turut digunakan bentuk penelitian empiris, dengan mengumpulkan data dari hasil survei di lapangan.

Penelitian yuridis normatif yang utama untuk kajian ini berupa berbagai bentuk peraturan perundang undangan. Literatur-literatur seperti jurnal, buku-buku, artikel-artikel, hasil-hasil penelitian, bentuk-bentuk laporan lainnya sebagai bahan hukum sekunder, juga digunakan dalam tulisan ini. Adapun kamus, ensiklopedia, peta dan lain-lainnya turut pula dipakai untuk melengkapinya sebagai bahan hukum tersier.

\section{PEMBAHASAN}

\subsection{Kebijakan Pemerintah Propinsi Riau Dalam Melindungi Potensi-Potensi IG Yang Ada Di Propinsi Riau Berdasarkan Undang-Undang Nomor 20 Tahun 2016}

Dalam pelaksanaan perlindungan terhadap IG yang ada di Propinsi Riau, pertama-tama haruslah diketahui berkenaan dengan pengetahuan di masyarakat mengenai indikasi geografis dan perkembangannya di propinsi Riau. Hasil servei terhadap Camat Tebing Tinggi Timur saat dipertanyakan mengenai pengertian dari IG dan peraturan yang mengaturnya Ia katakan:

"Indikasi Geografis merupakan sebuah produk tanaman yang memiliki ciri khusus berdasarkan geografis suatu daerah, yang hampir sama dengan merek yaitu dengan didaftarkan ke kementerian Hukum dan HAM sehingga manfaatnya semakin tinggi buat manusia dan dapat dijual dengan nilai yang tinggi. Untuk perundangan yang mengaturnya saya tidak mengetahuinya tapi saya tahu ada perundangan yang mengaturnya. Dan wujud indikasi geografis yang ada di Propinsi Riau yaitu: kopi liberika rangsang meranti."7

Pasal 70 Undang-undang Nomor 20 Tahun 2016 Tentang Merek dan Indikasi Geografis mewajibkan pemerintah pusat dan/atau pemerintah daerah melakukan

\footnotetext{
7 Wawancara yang dilakukan terhadap Camat Tebing Tinggi Timur H. Suyatno, S. Pd., M. M., 27 Desember 2019.
} 
kegiatan untuk melindungi IG, seperti: Persiapan untuk pemenuhan persyaratan permohonan indikasi geografis, Mengajukan permohonan pendaftaran indikasi geografis, pemanfaatan dan komersialisasi indikasi geografis, Sosialisasi perlindungan indikasi geografis kepada masyarakat, Pemetaan dan inventarisasi potensi produk indikasi geografis, pelatihan dan pendampingan, pemantauan, evaluasi, dan pembinaan, Memberikan perlindungan hukum, dan akhirnya memfasilitasi pengembangan, pengolahan, dan pemasaran barang dan/atau produk indikasi geografis.

Penggunaan tanda sebagai IG dapat berupa etiket atau label yang diletakkan pada barang yang dihasilkan. Tanda itu dapat berupa nama tempat, daerah, atau wilayah, kata, gambar, huruf, atau kombinasi dari unsur unsur tersebut. Perlindungan IG meliputi barang barang yang dihasilkan oleh alam, barang hasil pertanian, hasil kerajinan tangan; atau hasil industri lainnya. ${ }^{8}$

Sementara adanya aturan mengenai IG di Indonesia merupakan salah satu bentuk norma perlindungan $\mathrm{HKI}$, yang hadir setelah keikutsertaan dan ratifikasi Indonesia dalam persetujuan TRIPs (vide Keppres Nomor 7 Tahun 1994).

Serupa dengan perlindungan Merek di Indonesia, perlindungan IG pada akhirnya mensyaratkan adanya suatu proses permohonan pendaftaran. Hanya saja pendaftaran dilakukan oleh kelompok masyarakat atau institusi yang mewakili atau memiliki kepentingan atas produk bersangkutan.

Berdasarkan analisis bahwa syarat objektif sebagaimana yang telah diuraikan di atas adalah merupakan unsur-unsur yang akan menadakan reputasi, kualitas, dan karateristik yang harus ditunjukkan melalui sebuah produk berpotensi IG. Unsurunsur tersebut diteliti dengan tujuan untuk proses perolehan perlindungan hukum IG. Syarat subjektif merupakan syarat yang menerangkan siapa saja yang dapat mendaftarkan perlindungan hukum terhadap IG. Setelah mendaftarkan produk yang memiliki potensi IG dan memperoleh perlindungan hukum melalui IG masyarakat tersebut memiliki hak eksklusif untuk mengedarkan dan memperdagangkan produknya sehingga masyarakat daerah lain dilarang untuk menggunakannya pada produk mereka.

8 Yusran Isnaini, (2010), Buku Pintar HAKI Tanya Jawab Seputar Hak Kekayaan Intelektual, (Bogor, Ghalia Indonesia, hlm. 133 
Hukum pada prinsipnya adalah sesuatu yang tidak kelihatan, namun dalam aplikasinya bisa berbentuk nyata. Ia baru dapat dinilai baik jika akibat-akibat yang ditimbulkan dari penerapannya adalah kebaikan, kebahagian yang sebesar-besarnya dan berkurangnya penderitaan.

Indonesia merupakan negara yang berdasarkan hukum dilandasi Undang Undang Dasar Negara Republik Indonesia Tahun 1945. Pancasila adalah sebagai dasar negara dan sumber dari segala sumber hukum, sekaligus sebagai pandangan hidup bangsa. Artinya, bahwa segala sesuatu yang bertentangan dengan Pancasila dan UUD 1945 adalah dilarang dan tidak sah.

Mengenai kebijakan Pemerintah dengan tujuan perlindungan hukum terhadap IG di Propinsi Riau yaitu: apakah ada kebijakan pemerintah pusat dan daerah berkenaan dengan pengembangan IG. Jika ada, dapatkan bapak ceritakan apa saja kebijakan pemerintah Propinsi Riau tersebut? Camat Tebing Tinggi Timur Kabupaten Kepulauan Meranti menjawab pertanyaan tersebut sebagai berikut:

"Bahwa sepengetahuan Saya Pemerintah dalam hal ini Dinas Pertanian melakukan sosialisasi dengan cara mengumpulkan masyarakat tani di beberapa kecamatan dan melakukan penyuluhan atau seminar mengenai indikasi geografis. Namun untuk tindakan lainnya Saya tidak monitor". 9

Dalam suatu IG tersirat adanya suatu identitas sekaligus menunjuk pada daerah dimana barang tersebut berasal. Nama daerah, wilayah, tempat tersebut berhubungan dengan alam sebagai tanda karena ciri-ciri dan kualitas barang yang dihasilkan dipengaruhi oleh faktor-faktor geografis yang hanya ada di daerah tersebut, sehingga karena faktor-faktor IG tersebut memberikan ciri dan kualitas tertentu pada barang yang dihasilkan.

Dalam rangka meningkatkan efisiensi dan efektivitas penyelenggaraan pemerintahan otonom, masing-masing daerah harus berupaya senantiasa menggali potensi yang mereka miliki, berupaya memajukan sumber daya manusia, serta melakuka pembinaan terhadap macam-macam kegiatan ekonomi yang kreatif demi mendorong terwujudnya kesejahteraan masyarakat.

\footnotetext{
${ }_{9}^{9}$ Wawancara yang dilakukan terhadap Camat Tebing Tinggi Timur H. Suyatno, S. Pd., M. M., 27 Desember 2019.
} 


\subsection{Faktor-faktor Penghambat Pelaksanaan IG Di Propinsi Riau Menurut Undang-undang Nomor 20 Tahun 2016 Tentang Merek Dan Indikasi Geografis}

Perlindungan IG bertujuan untuk melindungi kekhasan suatu produk IG dari pemalsuan atau pemanfaatan yang tidak seharusnya sekaligus memberikan kesempatan dan perlindungan kepada masyarakat wilayah penghasil produk khas untuk mendapatkan manfaat yang maksimal dari produk khas tersebut. IG ini digunakan sebagai asset untuk mensejahterakan masyarakat di suatu wilayah dalam Negara, khususnya daerah apabila pemerintah lebih memiliki inisiatif untuk mengembangkan potensi alam yang dimiliki oleh suatu daerah dengan tepat dan bijaksana. Hal ini dapat terwujud apabila didukung sumber daya manusia yang memadai. Namun pada perkembangannya di Propinsi Riau, IG terkesan kurang dipahami oleh masyarakat lokal di daerah-daerah kabupaten di Propinsi Riau. ${ }^{10}$ Dengan demikian agar IG ini bisa benar-benar memberikan manfaat bagi suatu daerah dan/atau komunitas yang berhak sehingga perlu diidentifikasi faktor-faktor yang menghambat pelaksanaan Undang-undang Nomor 20 Tahun 2016 Tentang Merek dan Indikasi geografis.

\section{Syarat Pendaftaran IG}

Pendaftaran merek bertujuan untuk memperoleh kepastian hukum dan perlindungan hukum terhadap hak atas merek. Pedaftaran merek dilakukan pada Direktorat Jendral Hak Kekayaan Intelektual. Direktorat Jendral HKI adalah instansi pendaftaran merek yang ditugaskan untuk mendaftarkan merek yang dimohonkan pendaftarannya oleh pemilik merek. Pendaftaran merek dilakukan dengan memenuhi syarat-syarat sebagaimana telah ditentukan oleh UU No. 15 Tahun 2001.

Pandangan yang menyatakan rumitnya pendaftaran IG ini hanyalah pemikiran pendek dari masyarakat itu sendiri. Karena rendahnya faktor pendidikan yang dimiliki masyarakat itu, persyaratan yang diberikan oleh Dirjen Kekayaan intelektual dianggap sulit oleh masyarakat. Hal di atas berbanding lurus dengan pernyataan di bawah

ini.

10 Wawancara yang dilakukan terhadap Camat Tebing Tinggi Timur H. Suyatno, S. Pd., M.M., 27 Desember 2019. 
“...Kemajuan teknologi digital memudahkan para petani dan pengusaha dapat melakukan akses ke Kementerian Hukum dan Ham. Akses tersebut yaitu: formulir pendaftaran IG dapat diunduh dan diisi, kemudian dibawa bersamasama dengan produk yang dihasilkan tersebut untuk dapat dilakukan penelitian substansi di laboratorium oleh petugas Substansi IG. Kemudahan-kemudahan itu terlihat juga pada saat pengumuman yang dicantumkan di website resmi Kementrian Hukum dan Ham. Jadi tidak perlu bolak balik ke kantor Kementerian Hukum dan Ham karena komunikasi dapat dilakukan dengan email dan website...".11

Sehingga untuk menghindari pemikiran sulitnya prosedur pendaftaran IG, maka pemerintah daerah beserta perangkat Rukun Tetangga dan Rukun Warga dapat memulai komunikasi dua arah melalui seminar, penyuluhan, workshop mengenai pendaftaran IG. Pemerintah daerah harus dapat berperan menjadi fasilitator dalam mewujudkan pelaksanaan Undang-undang Nomor 20 Tahun 2016 Tentang Merek dan Indikasi Geografis.

\section{Kesadaran Hukum Masyarakat Propinsi Riau Rendah Terhadap IG}

Kesadaran yang Penulis maksud mengarah kepada kurangnya perhatian dan kepedulian dari Pemerintah dalam menjalankan fungsi dan peranannya untuk melakukan sosialisasi terlebih lagi dalam rangka pembinaan kepada masyarakat untuk menjadikan masyarakat mengerti dan paham terhadap manfaat dari IG tersebut.

\section{Pemerintah Propinsi Riau belum Menjadi Koordinator terhadap Instansi - instansi yang berkaitan dengan IG}

Hukum progresif ${ }^{12}$ mengajarkan bahwa hukum bukan raja, tetapi sebagai alat untuk menjabarkan dasar kemanusiaan yang berfungsi memberikan rahmat kepada dunia dan manusia. Asumsi yang mendasari progresifisme hukum adalah pertama hukum ada untuk manusia dan tidak untuk dirinya sendiri, kedua hukum selalu berada pada status law in the making dan tidak bersifat final, ketiga hukum adalah institusi yang bermoral kemanusiaan.

Maka setiap pegawai pemerintah dapat melakukan sosialisasi secara informal kepada para tentangga maupun keluarga walaupun ia tidak diwajibkan oleh Negara

11 Wawancara dengan Kasi Pemeriksaan Substansi Indikasi Geografis Bapak Saky Septiono, S. H., M. H., di Menkumham (Jakarta), tanggal 24 Desember 2019.

12 Satjipto Rahardjo (2005), "Hukum Progresif: Hukum yang Membebaskan", Jurnal Hukum Progresif, Vol. 1, No. 1/April, Program Doktor Undip Semarang, hlm. 3. 
untuk melakukan itu. Sementara di kantor, program tahunan dan bulanan dapat direncanakan dan dimaksimalkan untuk melakukan hal baik dalam meningkatkan kualitas produk IG yang sudah terdaftar maupun yang belum terdaftar. Misalnya: mengkoordinasikan dengan ahli desain grafis untuk membuat kemasan atau bungkus dari kopi liberika rangsang meranti mejadi lebih indah, dan mempromosikannya pada saat dilakukan pameran oleh instansi lain di luar daerah atau luar negeri.

Hal di atas dinyatakan oleh Abd Thalib yang menyatakan bahwa perlindungan dan pembangunan berada dalam cakupan teknologi, inovasi, pengembangan, dan pembuatan kebijakan, sebagai berikut: ${ }^{13}$

"Dalam masa lima puluh tahun ini pengembangan dan kemajuan dalam berbagai aspek kehidupan telah dicapai, Dalam waktu yang sama, pemahaman terhaap proses dan lembaga-lembaga yang mempengaruhi keberadaan teknologi telah berubah. Negara yang peduli dengan usaha peningkatan dalam bidang teknologi telah menunjukkan kemajuan yang pesat. Masing-masing berada pada tingkatan-tingkatan yang berbeda satu dengan yang lainnya".

\section{Belum cukupnya Tenaga Ahli dalam mengontrol Produk IG yang berkualitas}

Kekurangan tenaga ahli harus dapat menjadi perhatian Utama dari Pemerintah Pusat agar Undang-undang Nomor 20 tahun 2016 dapat dilaksanakan dengan baik. Hal itu juga dinyatakan oleh Abd Thalib: ${ }^{14}$

"It should be noted however, that the General Policy towards the skill problem of Indonesian national manpower is, that efforts should be made to enhance knowledge, improve skill, augment the ability to organise and manage. In pursuance of this General Policy we may emphasize that within the framework of mineral oil and gas mining, the above mentioned efforts should also be made by the Government, i.e., the State Oil Enterprise."

Perlindungan IG sebagai upaya peningkatan kualitas masyarakat sudah saatnya direalisasikan. Potensi daerah harus digali seiring mewujudkan perekonomian berbasis kerakyatan, karena hasil ekonomi dari perlindungan IG akan

13 Abd Thalib, (2016), Shortcomings Technology Transfer In Indonesia: A Critical Appraisal, International Information Intitute, Vol 19, Number 6(A), Juni

${ }^{14}$ Abd Thalib's Thesis (2012), "Pemindahan Teknologi di Indonesia: Kajian Perundangan", (Tesis, non-publikasi), Fakulti Undang-Undang, Universiti Malaya, hlm. 128-193. 
digunakan/dikembalikan lagi ke masyarakat. Agar IG menjadi aset daerah yang potensial untuk dikomersilkan adalah: ${ }^{15}$

1. Dilakukan inventarisasi produk daerah yang memunyai reputasi/ dikenal luas dan berpotensi ekonomi.

2. Dilakukan penelitian tentang apa saja ciri atau kekhasan yang bisa diangkat pada produk tertentu agar mendapat perlindungan dari segi IG;

3. Mencari dan menetapkan batas-batas geografis berdasarkan pengaruh terbesar yang menyebabkan adanya ciri dan kualitas tersebut. Cara agar suatu indikasi dapat ditemukan dari keadaan geografis tersebut.

\section{PENUTUP}

\subsection{Kesimpulan}

Kebijakan Pemerintah Propinsi Riau dalam memberikan perlindungan hukum terhadap IG di Propinsi Riau tidak berjalan sebagaimana yang diharapkan. Terbukti belum adanya Peraturan Daerah di Propinsi maupun kabupaten dan kota yang mengatur tentang IG. Tidak adanya lembaga yang menkoordinir dalam mengangkat dan mengembangkan terhadap potensi IG yang dimiliki masing-masing daerah. Sosialisasi kepada masyarakat oleh pemerintah daerah khususnya instansi terkait hampir sama sekali tidak pernah dilakukan. Tidak adanya pengawasan dalam menerapkan pelaksanaan peraturan yang sudah ada, serta belum diatur mengenai hak dan kewajiban pemilik IG.

Faktor penghambat dalam melindungi IG yang ada di Propinsi Riau adalah belum adanya Peraturan Daerah yang mengatur tentang IG, kesadaran hukum masyarakat Propinsi Riau yang rendah terhadap IG, serta tidak adanya jiwa kewirausahaan di kalangan aparat Pemerintah Propinsi Riau pada umumnya, dan para pejabat kabupaten/kota pada khususnya. Faktor lain yang juga tidak kalah pentingnya adalah belum cukupnya tenaga ahli dalam mengontrol produk IG yang berkualitas.

15 Wawancara dengan Kasi Pemeriksaan Substansi Indikasi Geografis Bapak Saky Septiono, S. H., M. H., di Menkumham (Jakarta) pada tanggal 24 Desember 2019. 


\subsection{Saran}

Agar Potensi IG di tingkat Propinsi dan kabupaten/daerah dapat maju dan berkembang, sekaligus memberikan perlindungan hukum terhadap produk IG yang sudah maupun yang belum ada dapat dilaksanakan dengan baik, dituntut suatu kebijakan lintas sektoral oleh Pemerintah Propinsi kepada pemerintah kabupaten/kota hingga para stake holder terkait, supaya memihak kepada produsen dalam negeri, dan membuat Peraturan Daerah untuk mengaturnya lebih dalam. Terhadap pemilik IG yang belum terkenal, supaya dilakukan penambahan tenaga ahli sehingga produk IG dapat dievaluasi secara berkala dan perbaikan selalu dilakukan terhadap pengusaha dan UMKM di daerah-daerah.

\section{DAFTAR PUSTAKA}

Isnaini, Yusran (2010), Buku Pintar HAKI Tanya Jawab Seputar Hak Kekayaan Intelektual, Bogor, Ghalia Indonesia.

Permata, Rika Ratna, Sudaryat, dan Sudjana (2010), Hak Kekayaan Intelektual, Memahami Prinsip Dasar, Cakupan Dan Undang-Undang Yang Berlaku, Oase Media, Bandung.

Rahardjo, Satjipto (2005), "Hukum Progresif: Hukum yang Membebaskan", Jurnal Hukum Progresif, Vol. 1, No. 1/April, Program Doktor Undip Semarang.

Tavinayati, M. Effendy, Zakiyah dan M. Taufik Hidayat (2016), Perlindungan terhadap hak kekayaan inteletktual, indikasi geografis hasil pertanian lahan basah sebagai produk khas Propinsi Kalimantan Selatan, Badamai Lau Journal bol.1, Issue 1, fakultas Hukum Universitas Lampung, Lampung, April.

Thalib, Abd (2016), Shortcomings Technology Transfer In Indonesia: A Critical Appraisal, International Information Intitute, Vol 19, Number 6(A), Juni.

Thalib, Abd (2012), “Pemindahan Teknologi di Indonesia: Kajian Perundangan”, (Tesis non-publikasi), Fakulti Undang-Undang, Universiti Malaya.

Konvensi Paris Tahun 1883 Tentang Perlindungan Kekayaan Industri.

Undang-Undang Dasar Negara Republik Indonesia Tahun 1945.

Undang-Undang Nomor 20 Tahun 2016 Tentang Merek dan Indikasi Geografis.

Undang-Undang Nomor 15 Tahun 2001 Tentang Merek.

Undang-undang Nomor 7 Tahun 1994 Tentang Pengesahan Agreement Establishing the World Trade Organization (TRIPs). 
Undang-Undang Nomor 23 Tahun 2014 Tentang Pemerintahan Daerah.

Peraturan Pemerintah Nomor 2 Tahun 1945 Tentang Badan-Badan dan Peraturan Pemerintah Dulu.

Peraturan Pemerintah Nomor 51 Tahun 2007 Tentang Indikasi Geografis.

https://doi.org/10.1111/jwip/12073 